\title{
FOCUS GROUP DISCUSSION TENTANG PENCEGAHAN RISIKO BUNUH DIRI TERHADAP PERILAKU RISIKO BUNUH DIRI PADA REMAJA BERISIKO
}

\author{
Kadek Dicky Nugraha ${ }^{1 *}$, Miftakhul Ulfa $^{2}$,Ahmad Guntur Alfianto ${ }^{3}$ \\ ${ }^{1}$ Sekolah Tinggi Ilmu Kesehatan Widyagama \\ Husada Malang \\ ${ }^{2}$ Sekolah Tinggi Ilmu Kesehatan Widyagama \\ Husada Malang \\ ${ }^{3}$ Sekolah Tinggi Ilmu Kesehatan Widyagama \\ Husada Malang

\section{Abstract} \\ Backgorund: One of the problems in teenagers is suicide. Suicide is one of the impacts of psychiatric \\ disorder that is the current global spotlight. One of the prevention of suicide risks in teenagers can be \\ done by a focus group discussion $(f g d)$. Objective: Analyze the influence of fgd on suicide risk \\ prevention against suicide risk behaviors in adolescents at risk. Research methods: This research used \\ experimental quasi pretest-posttest with control group design with 15 students for the control group \\ and 15 students for the intervention group. Which taken using total sampling technique. Instruments to \\ assess suicide risk behaviors used Beck Suicidal Intent Scale. Scores for suicide behaviours before and \\ Corresponding author: \\ Miftakhul Ulfa \\ Sekolah Tinggi Ilmu Kesehatan Widyagama \\ Husada Malang \\ Email:mimiulfah336@gmail.com \\ after given a fgd were analysed with Wilcoxon statistical trials.Result: Wilcoxon test analysis results \\ obtained $P=0.55$ which means $p>0.05 .15$ it means that there is no influence offgd on the prevention \\ of suicide risk against suicide risk behavior in adolescents at risk Conclusion: There was no influence \\ offgd on the prevention of suicide risk against suicide risk behavior in adolescents at the risk of 1 \\ Bululawang High School.Tip: Further researchers are expected to add longer research time in \\ subsequent studies to explore information on the risk of suicide.
}

Keywords: Teenagers : fgd;suicide risk;psychosocial problems

\begin{abstract}
Abstrak
Latar Belakang : Salah satu permasalahan pada remaja adalah bunuh diri. Bunuh diri merupakan salah satu dampak dari gangguan kejiwaan yang menjadi sorotan global saat ini. Salah satu pencegahan risiko bunuh diri pada remaja dapat dilakukan dengan cara focus group discussion(fgd).Tujuan : Menganalisa pengaruh fgd tentang pencegahan resiko bunuh diri terhadap perilaku risiko bunuh diri pada remaja berisiko. Metode Penelitian :Desain penelitian ini menggunakan quasi eksperimentalpretest-posttest with control group design dengan sampel berjumlah 15 siswa untuk kelompok kontrol dan 15 siswa untuk kelompok intervensi. Teknik pengambilan sampel secara total sampling. Instrumen untuk menilai perilaku risiko bunuh diri menggunakan Beck Suicidal Intent Scale. Skor untuk perilaku risiko bunuh diri sebelum dan sesudah diberikan fgddianalisa dengan uji statistik Wilcoxon. Hasil : Hasil analisis uji Wilcoxon didapatkan $\mathrm{p}=0,55$ yang berarti $\mathrm{p}>0,05$. Inimenunjukkan bahwa tidak ada pengaruh fgdtentang pencegahan risiko bunuh diri terhadap perilaku risiko bunuh diri pada remaja berisiko Kesimpulan : Tidak terdapat.pengaruh fgd tentang pencegahan risiko bunuh diri terhadap perilaku risiko bunuh diri pada remaja berisiko di Sekolah Menengah Atas Negeri 1 Bululawang. Saran : Peneliti selanjutnya diharapkan menambahkan waktu penelitian yang cukup lama dalam penelitian selanjutnya untuk menggali informasi mengenai risiko bunuh diri.
\end{abstract}

Kata Kunci: Remaja : fgd;risiko bunuh diri; masalah psikososial 


\section{PENDAHULUAN}

Usia paling rentang untuk melakukan tindakan bunuh diri adalah pada usia remaja (10 -19 tahun), dimana pada periode ini merupakan fase transisi dari anak menjadi orang dewasa yang diikuti oleh perubahan biologis, kognitif dan sosioemosional (WHO, 2015). Dalam menghadapi persoalan tersebut, masing-masing individu mempunyai cara yang berbeda sehingga dapat memunculkan berbagai suasana hati dan perasaan. Bagi individu yang tidak dapat mengespreksikan suasana hati dan perasaan, dapat mengakibatkan.

Pravelensi gangguan mental emosional yang di tunjukkan dengan gejala-gejala depresi dan kecemasan untuk usia 15 tahun ke atas mencapai 14 juta orang atau 6\% dari jumlah penduduk Indonesia. Pada kelompok usia 15-24 tahun, prevalensi gangguan mental emosional sebesar 5,6\% (Riskesdas, 2013). Faktor-faktor yang menyertai gejala depresi pada remaja yaitu adanya perselisihan dengan teman sebaya biasanya terjadinya (bullying), adanya perselisihan keluarga, kesulitan mengikuti pelajaran, dan rendahnya rasa percaya diri (Ashirita \& Ariani, 2019). Masalah-masalah psikososial tesebut bisa berdampak buruk bagi siswa salah satunya adalah risiko bunuh diri. Peneliti depresi. melakukan screening menggunakan alat ukur (Horowitz et al., 2012)(ASQ) di salah satu sekolah menengah atas negeri (SMAN) di kabupaten Malang didapatkkan hasil sebanyak 48,9\% siswa mengalami acute positive screen atau risiko bunuh diri dari 163 (100\%) siswa di SMAN tersebut. Selain itu dari hasil wawancara 4 orang siswa yang berisiko bunuh diri mengatakan cara agar terhindar dari perilaku bunuh diri dengan curhat ke teman yang dipercaya, berkumpul dengan orang lain, selalu berpikir positif, mengalihkan perhatian ke hal lain
Pendekatan sekolah sehat jiwa salah satunya sebagai upaya menurunkan masalah psikososial pada remaja di lingkungan sekolah. Sekolah sehat jiwa tersebut dapat di bentuk melalui unit kesehatan sehat jiwa. (Guntur et al., 2019). Upaya yang dapat dilakukan di sekolah sehat jiwa dengan melakukan konseling perawat dengan siswa yang mengalami masalah psikososial yang dapat menyebabkan risiko bunuh diri. SMAN di kabupaten Malang tersebut tidak memiliki program sekolah sehat jiwa, sehingga upaya yang dapat dilakukan dengan melakukan focus group discussion pada siswa yang memiliki masalah psikososial yang menyebabkan risiko bunuh diri (Varcarolis \& Halter, 2010).

Berdasarkan masalah tersebut peneliti ini bertujuan untuk menganalisis efektifitas FGD tentang pencegahan risiko bunuh diri terhadap perilaku risiko bunuh diri pada remaja berisiko di salah satu SMAN kabupaten Malang. Penelitian ini termasuk jenis penelitian eksperimen dengan menggunakan metode Quasi Eksperimental.

\section{METODE}

Penelitian ini menggunakan desain penelitian quasi experimental dengan pendekatan pretest-posttest with control group design. Populasi dalam penelitian ini adalah siswa-siswi yang memiliki masalah psikososial dengan risiko bunuh diri di salah satu SMAN kota Malang. Teknik sampling yang digunakan adalah total sampling dengan jumlah sampel sebanyak 30 responden. kriteria inklusi antara lain siswasiswi yang memiliki risiko bunuh diri yang sebelumnya di screening menggunakan ASQ (Horowitz et al., 2012).

Alat ukur yang digunakan dalam penelitian ini menggunakan kusioner Beck Suicidal Intent Scale (BSIC). BSIC tediri dari 15 pertanyaan yang terdiri dari 5 komponen suicidal idention. Komponen tesebut adalah intensity, active suicidaldesire/suicidal 
ideation, passive suicidaldesire suicidal ideation, planning, concealment. Kuesioner terdiri dari tiga pilihan bertingkat mengacu pada intensitas seputar bunuh diri dan memiliki rentang poin 0 sampai 2 . Hasil dari BSIC adalah 0-10 rendah, 11-20 sedang, dan 20-30 tinggi.

Metode pengumpulan data dengan melakukan screening menggunakan ASQ kepada 163 siswa-siswi di salah satu SMAN Kabupaten Malang. Pengumpulan data dilakukan dari bulan Februari 2020 hingga Juni 2020. Hasil yang di dapatkan 30 (48,9\%) siswa-siswi memiliki risiko bunuh diri. 30 sisa-siswi tersebut terbagi menjadi 2 kelompok yaitu kelompok perlakuan dan kelompok kontrol. Prosedur pengumpulan data dilakukan pada kelompok perlakuan yaitu responden mengisi kuesioner BSIC.

FGD diberikan kepada kelompok perlakuan dengan 1 kali tatap muka melalui aplikasi zoom. Diakhiri kegiatan responden mengisi kuesioner BSIC (pretest), kemudian responden mengisi kuesioner BSIC (posttest).

Analisa data menggunakan analisa univariat dan bivariat. Analisa bivariat dilakukan uji beda pretest dan posttest pada masing-masing kelompok dengan menggunakan uji wilcoxon test.

\section{HASIL}

Tabel 1. Karakteristik Responden Berdasarkan Usia

\begin{tabular}{ccccc}
\hline Usia & \multicolumn{4}{c}{ Kelompok } \\
& Focus Group Discussion & \multicolumn{2}{c}{ Leaflet } \\
\cline { 2 - 5 } & Jumlah & Presentase & Jumlah & Presentase \\
& $(\mathrm{f})$ & $(\%)$ & $(\mathrm{f})$ & $(\%)$ \\
16 & 2 & $13.3 \%$ & 3 & $20 \%$ \\
17 & 12 & $80 \%$ & 12 & $80 \%$ \\
18 & 1 & $6.7 \%$ & - & - \\
Total & 15 & $100 \%$ & 15 & $100 \&$ \\
\hline
\end{tabular}

Berdasarkan hasil penelitian menunjukan bahwa sebagian besar responden dalam kelompok Focus Group Discussion adalah berusia 17 yaitu sebanyak 12 responden (80\%), sedangkan dalam kelompok leaflet diketahui sebagian besar responden berusia 17 yaitu sebanyak 12 responden $(80 \%)$.

Tabek 2. Karakteristik Responden Berdasarkan Jenis Kelamin

\begin{tabular}{ccccc}
\hline Jenis & \multicolumn{4}{c}{ Kelompok } \\
Kelamin & \multicolumn{2}{c}{ Focus Group } & \multicolumn{2}{c}{ Leaflet } \\
\cline { 2 - 5 } & \multicolumn{2}{c}{ Discussion } & & \\
\cline { 2 - 5 } & Jumlah & Presentase & Jumlah & Presentase \\
Laki-Laki & 3 & $(\%)$ & $(\mathrm{f})$ & $(\%)$ \\
Perempuan & 12 & $20 \%$ & 5 & $33.3 \%$ \\
Total & 15 & $100 \%$ & 10 & $66.7 \%$ \\
\hline
\end{tabular}

Berdasarkan hasil penelitian menunjukkan bahwa sebagian besar responden kelompok Focus Group Discussion adalah perempuan yaitu sebanyak 12 responden (80\%), sedangkan dalam kelompok leaflet diketahui sebagian besar responden adalah perempuan yaitu sebanyak 10 responden $(66.7 \%)$.

\section{Karakteristik Responden Berdasarkan Masalah} Psikososial Yang Dihadapi

\begin{tabular}{ccccc}
\hline Masalah & \multicolumn{4}{c}{ Kelompok } \\
Psikosial & \multicolumn{2}{c}{ Focus Group } \\
& \multicolumn{2}{c}{ Discussion } & \multicolumn{2}{c}{ Leaflet } \\
\cline { 2 - 5 } & Jumlah & Presentase & Jumlah & Presentase \\
& $(\mathrm{f})$ & $(\%)$ & $(\mathrm{f})$ & $(\%)$ \\
Cemas & 11 & $73.3 \%$ & 10 & $66.7 \%$ \\
Menarik & 2 & $13.3 \%$ & 2 & $13.3 \%$ \\
Diri & & & & \\
Depresi & 1 & $6.7 \%$ & 2 & $13.3 \%$ \\
Tekanan & 1 & $6.7 \%$ & 1 & $6.7 \%$ \\
teman & & & & \\
sebaya & & - & & - \\
Bullying & - & $100 \%$ & 15 & $100 \%$ \\
Total & 15 & & & \\
\hline
\end{tabular}

Berdasarkan hasil penelitian menunjukkan bahwa sebagian besar masalah psikososial yang dihadapi responden kelompok Focus Group Discussion adalah cemas yaitu sebanyak 11 responden (73.3\%), sedangkan dalam kelompok leaflet diketahui sebagian besar masalah psikososial yang dihadap responden adalah cemas yaitu sebanyak 10 responden $(66.7 \%)$. 
Tabel 4. Sebelum Diberikan Perlakuan Focus Group Discussion

\begin{tabular}{ccc}
$\begin{array}{c}\text { Perilaku responden } \\
\text { sebelum perlakuan }\end{array}$ & $\begin{array}{c}\text { Jumlah } \\
\text { (f) }\end{array}$ & $\begin{array}{c}\text { Presentase } \\
(\%)\end{array}$ \\
Rendah & 6 & $40 \%$ \\
Sedang & 9 & $60 \%$ \\
Tinggi & - & - \\
Total & 15 & $100 \%$ \\
\hline
\end{tabular}

sebelum dilakukan perlakuan Focus Group

Discussion terhadap perilaku remaja berisiko.

Sebagian besar responden memiliki perilaku risiko bunuh diri sedang yaitu sebanyak 9 responden (60\%), sedangkan sebagian kecil memiliki perilaku risiko bunuh diri yang rendah yaitu sebanyak 6 responden (40\%).

Tabel 5. Sesudah Diberikan Perlakuan Focus Group Discussion

\begin{tabular}{ccc}
\hline $\begin{array}{c}\text { Perilaku Responden } \\
\text { Sesudah perlakuan }\end{array}$ & $\begin{array}{c}\text { Jumlah } \\
\text { (f) }\end{array}$ & $\begin{array}{c}\text { Presentase } \\
(\%)\end{array}$ \\
Rendah & 8 & \\
Sedang & 7 & $53.3 \%$ \\
Tinggi & - & $46.7 \%$ \\
Total & 15 & - \\
\hline
\end{tabular}

sesudah dilakukan perlakuan Focus Group Discussion terhadap perilaku remaja berisiko. Sebagian besar responden memiliki perilaku risiko bunuh diri rendah yaitu sebantak 8 responden $(53.3 \%)$, sedangkan sebagian kecil memiliki perilaku risiko bunuh diri yang sedang yaitu sebanyak 7 responden $(46.7 \%)$.

Tabel 6.

\begin{tabular}{|c|c|c|c|c|c|}
\hline \multirow[t]{2}{*}{$\begin{array}{c}\text { Perila } \\
\text { ku }\end{array}$} & \multicolumn{2}{|c|}{$\begin{array}{c}\text { Sebelum } \\
\text { Perlakuan } \\
\end{array}$} & \multicolumn{2}{|c|}{ Setelah Perlakuan } & $\begin{array}{l}\text { Signifik } \\
\text { asi } \\
\end{array}$ \\
\hline & $\begin{array}{c}\text { Frekue } \\
\text { nsi }\end{array}$ & $\begin{array}{l}\text { Persent } \\
\text { asi }\end{array}$ & $\begin{array}{c}\text { Frekue } \\
\text { nsi }\end{array}$ & $\begin{array}{l}\text { Persent } \\
\text { asi }\end{array}$ & 0,055 \\
\hline $\begin{array}{c}\text { Renda } \\
h\end{array}$ & 6 & $40 \%$ & 8 & $53.3 \%$ & \\
\hline $\begin{array}{c}\text { Sedan } \\
\mathrm{g}\end{array}$ & 9 & $60 \%$ & 7 & $46.7 \%$ & \\
\hline Tinggi & - & - & - & - & \\
\hline Total & 15 & $100 \%$ & 15 & $100 \%$ & \\
\hline
\end{tabular}

Hasil yang diperoleh dari analisis tabel 5.8 diketahui bahwa terdapat 15 responden yang mendapatkan perlakuan. Kategori rendah mengalami peningkatan dari $40 \%$ menjadi $53.3 \%$, kategori sedang menurun dari $60 \%$ menjadi $46.7 \%$.

\section{Pembahasan}

\section{A. Karakteristik Responden}

1. Karakteristik responden berdasarkan usia

Responden di dalam penelitian ini sebanyak 30 responden. Responden di bagi menjadi 2 kelompok. Responden yang berusia 16 tahun sebanyak 6 (16.7\%) responden, responden yang berusia 17 tahun sebanyak $24(80 \%)$ responden, responden yang berusia 18 tahun sebanyak $1(3.3 \%)$ responden. Sebelum dilakukan pendidikan kesehatan dengan metode focus group discussion responden mendapat kategori sedang sebanyak $9(60 \%)$ responden, dan kategori rendah sebanyak $6(40 \%)$ responden

Remaja merupakan periode perubahan besar bagi semua orang yang berusia muda dan dapat menimbulkan berbagai tantangan fisik, sosial, emosional dan akademis. Tahapan ini adalah waktu bagi orang yang berusia muda untuk membangun identitas mereka, mencari kemerdekaan yang lebih besar, tahapan transisi ke masa dewasa dan sering menghadapi tekanan dari sekolah dan lingkungan sosial. Tahapan ini juga merupakan usia puncak onset dari banyaknya gangguan kesehatan mental (Yeomans \& Christensen, 2016).

Tahapan masa remaja akhir yang seharusnya lebih mampu mengendalikan emosi, mampu menghadapi masalah dengan lebih tenang dan rasional. Namun, selama masa remaja status emosional remaja masih dalam keadaan berubah-ubah antara perilaku yang menunjukkan kedewasaan dengan perilaku seperti anak-anak. Pada tahapan remaja akhir, mereka sudah dewasa dalam berfikir namun masalah dalam tahapan ini juga akan semakin bertambah. Jenjang pendidikan yang semakin tinggi juga akan menuntut kegiatan akademis yang lebih 
padat. Stress akademik dapat berperan penting dalam menentukan kesehatan mental remaja (Subramani \& Kadhiravan, 2017).

Menurut Asante dkk (2017) menyebutkan bahwa risiko bunuh diri akan semakin meningkat pada jenjang usia yang lebih tinggi. Presentase ide bunuh diri, rencana bunuh diri dan percobaan bunuh diri memiliki persentase tinggi di usia 17 tahun dan 18 tahun ke atas (Oppong Asante, Kugbey, Osafa, Quarshie, \& Sarfo, 2017). pernyataan tersebut diperkuat dalam penelitian ini menunjukkan usia terbanyak yang mengalami risiko perilaku bunuh diri dan menjadi responden dalam penelitian ini adalah usia remaja akhir (16-24 tahun) sebanyak 15 responden (100\%) dan pada kelompok kontrol sebanyak 15 responden (100\%).

Peneliti meyakini bahwa usia remaja akhir merupakan tahapan dengan tingkat jiwa kompetitif yang lebih tinggi, selama penelitian rata-rata siswa mengatakan memiliki tanggung jawab yang besar dari orang tua untuk bisa mempertahankan dan menaikkan peringkat mereka. Namun, dalam prosesnya usaha yang mereka lakukan kadang kala belum sesuai dengan ekspektasinya sehingga pengharapan yang lebih besar membuat mereka menjadi stress dan merasa terbebani yang berakibat depresi.

2. Karakteristik responden berdasarkan jenis kelamin

Responden yang berjenis kelamin laki-laki sebanyak $8(26.7 \%)$ responden dan yang berjenis kelamin perempuan sebanyak 22 (73.3\%) responden. Responden yang mendapatkan kategori sedang terbanyak sebanyak 6 (46.7\%) responden dengan jenis kelamin perempuan, responden yang mendapat kategori rendah terbanyak sebanyak 5 (33.3\%) responden berjenis kelamin perempuan.

Pada masa remaja adalah masa peralihan, sehingga mulai terjadi perubahan baik fisik, biologis dan salah satunya juga psikologis. Perubahan psikologis pada perempuan lebih sensitif di banding laki-laki, karena perempuan akan memikirkan segala apa yang dilakukan, berbeda dengan laki-laki yang tidak terlalu memikirkan segalanya sehingga membuat perempuan lebih mendominan dari pada laki-laki

Apabila ditinjau dari jenis kelamin, laki-laki menunjukkan peluang melakukan bunuh diri (commit suicede) empat kali lebih banyak dari perempuan. Tetapi peluang bagi perempuan untuk melakukan percobaan bunuh diri (attempt suicede) empat kali lebih banyak dari pada laki-laki (steinberg, 1999). Sedangkan berdasarkan hasil penelitian Bertera dalam Aulia (2014) sikap yang menggambarkan ide bunuh diri pada perempuan lebih terlihat. Remaja laki-laki cenderung untuk mengekspresikan masalah emosional dalam bentuk agresivitas yang merupakan bentuk dari perilaku mencederai diri secara tidak langsung dan perilaku antisosial lainnya sementara perempuan cenderung menginternalisasi masalah dan menjadi depresi yang berujung pada perilaku bunuh diri.

Hasil penelitian ini sejalan dengan penelitian yang dilakukan oleh Pratiwi dan Undarwati (2014) di Semarang menjelaskan bahwa responden jenis kelamin perempuan lebih mendominan yaitu 267 responden $(60,41 \%)$ dari 442 responden remaja. Hasil penelitian Aulia (2016) di Rengat didapatkan hasil kelompok jenis kelamin perempuan lebih banyak yaitu sebesar 218 responden (59,7\%). Kemudian penelitian yang dilakukan oleh Rahmayanti dan Rahmawati (2018) menjelaskan karakteristik remaja sebagaian besar berjenis kelamin perempuan yaitu sebesar 56,2\%. Maka dari beberapa hasil penjelasan dari penelitian terkait karakteristik responden perempuan lebih mendominan daripada laki-laki.

Peneliti berpendapat bahwa pada masa remaja adalah masa peralihan, sehingga mulai terjadi perubahan baik fisik, biologis dan salah satunya juga 
psikologis. Perubahan psikologis pada perempuan lebih sensitif di banding laki-laki, karena perempuan akan memikirkan segala apa yang dilakukan, berbeda dengan laki-laki yang tidak terlalu memikirkan segalanya sehingga membuat perempuan lebih mendominan daripada laki-laki

3. Karakteristik masalah psikososial yang dihadapi responden

Responden di dalam penelitian ini sebanyak 30 responden yang mengalami masalah psikosisal. Responden di bagi menjadi 2 kelompok. Responden yang memiliki masalah cemas sebanyak $21(70 \%)$ responden, responden yang memiliki masalah menarik diri sebanyak 4 (13.3\%) responden, responden yang memiliki masalah depresi sebanyak 3 (10\%) responden, responden yang memiliki masalah tekanan dari teman sebaya sebanyak $2(6.7 \%)$.

Masalah-masalah psikososial yang dialami pada usia remaja/usia sekolah antara lain adalah masalah di rumah seperti bersikap kasar, di sekolah seperti prestasi buruk dan perilaku mengganggu, masalah dengan teman sebaya seperti kurang mempunyai teman dan antisosial serta suasana hati seperti depresi, ansietas dan sikap bermusuhan (Stuart, 2016). Selain itu remaja juga berisiko terhadap lingkungan sosialnya seperti pengangguran, perilaku agresif dan kriminalitas (Kusumaryani, 2017). Dari berbagai masalah psikososial yang dialami remaja dapat di kelompok yaitu masalah dalam diri dan di luar dirinya seperti teman sebaya, rumah atau keluarga, sekolah dan lingkungan sehingga remaja sulit berhasil dalam melalui masa berkembangnya. Masalah psikososial tersebut dapat berdampak masalah risiko bunuh diri. Risiko bunuh diri diakibatkan oleh stressor kehidupan, lingkungan dan psikologis, hal tersebut menyebabkan seseorang dengan adanya stressor dapat berkeinginan bunuh diri (Nock et al., 2013).
Assana dkk (2017) menyebutkan bahwa sebagian besar siswa SMA (usia remaja akhir) memiliki kualitas hidup yang rendah hingga sedang. Stress akibat pendidikan, kecemasan serta depresi berpengaruh terhadap QOL (quality of life) siswa yang berdampak pada kesehatan mental remaja. Sekitar $26 \%$ siswa SMA dalam penelitian tersebut memiliki tingkat stres pendidikan yang tinggi. Menurut Santrock, salah satu tahapan perkembangan remaja yaitu sering mengalami masa krisis identitas dan ambigu. Hal yang demikian menyebabkan remaja menjadi tidak stabil, agresif, mengalami konflik antara sikap dan perilaku, kegoyahan emosional dan sensitif,terlalu cepat dan gegabah untuk mengambil tindakan yang ekstrim. Adanya ciri khas sifat remaja yang mudah mengalami kegoyahan emosional dan gegabah tersebut menyebabkan remaja tidak mudah untuk mempertahankan emosinya yang positif, akhirnya berdampak pada tahap perkembangan remaja yang sering menunjukkan perilaku agresif baik kepada teman, orang tua maupun kepada orang lain yang lebih muda (Agustriyana, 2017).

Pada penelitian ini, remaja yang mengalami masalah memang cenderung untuk berfikir mengambil risiko untuk melukai dirinya, mereka berpikir bunuh diri dapat mengakhiri semua masalahnya, beberapa remaja yang sempat diwawancara oleh peneliti merasa bahwa orang-orang sekitarnya tidak ada yang peduli, mereka bahkan tampak tidak bergairah di dalam kelas.

\section{B. Sebelum dilakukan Focus Group Discussion}

Sebelum dilakukan pendidikan kesehatan focus group discussion terhadap perilaku risiko bunuh diri pada remaja berisiko, responden yang mendapat kategori sedang 9 (60\%) responden, responden yang mendapat kategoti rendah 6 (40\%) responden. Dimana 
bedasakan item dalam kuesioner ini ditujukan nilai tertinggi pada pikiran akan penyelamatan tim medis.

Jawaban dari responden berdasarkan indikator pencegahan risiko bunuh diri terdapat pengetahuan yang kurang hal ini dikarenakan kurangnya informasi yang didapatkan siswa hal ini sesuai dari hasil wawancara yaitu belum pernah diadakan pendidikan kesehatan mengenai pencegahan risiko bunuh diri, di SMAN 1 Bululawang belum tersedianya media kesehetan seperti poster, tidak memiliki UKS yang menjadi tempat curhat siswa yang memiliki risiko untuk bunuh diri, sehingga sangat memungkinkan bahwa responden mendapat kategori sedang. Dampak dari kurangnya responden mengetahui pencegahan risiko bunuh diri adalah berisiko melakukan tindakan bunuh diri.

\section{Sesudah Diberikan Perlakuan}

Sesudah dilakukan pendidikan kesehatan focus group discussion terhadap perilaku risiko bunuh diri pada remaja berisiko, responden yang mendapat kategori rendah $8(53,3 \%)$ responden, responden yang mendapat kategori sedang $7(46,7 \%)$ responden. Dimana berdasarkan item kusioner terkait pikiran akan penyelamatan tim medis, setelah dilakukan focus group discussion FGD para responden mengetahui peran pentingnya tim medis untuk mencegah tindakan bunuh diri.

Risiko bunuh diri dapat diartikan sebagai resiko individu untuk menyakitidiri sendiri, mencederai diri, serta mengancam jiwa. Perilaku bunuh diri disebabkan karena stres yang tinggi dan berkepanjangan dimana individu gagal dalam melakukan mekanisme koping yang digunakan dalam mengatasi masalah(Nanda, 2012).

Menurut Sutejo (2017) Etiologi dari resiko bunuh diri meliputi : faktor genetik, faktor biologis, faktor psikosoisal dan lingkungan, dan stressor lingkungan.
Faktor genetik mempengaruhi terjadinya resiko bunuh diri pada keturunannya. Faktor biologis ini biasanya berhubungan dengan keadaan-keadaantertentu, seperti adanya penyakit kronis atau kondisi medis tertentu. Faktor psikosisal dan lingkungan berdasarkan teori psikoanalitik atau psikodinamika, bunuh diri merupakan hasil dari marah yang diarahkan pada diri sendiri, yaitu bahwa kehilangan objek berkaitan dengan agresi dan kemarahan, perasaan negative terhadap diri sendiri dan terakhir depresi. Faktor stressor lingkungan yaitu kehilangan anggota keluarga, penipuan, kurangnya sistem dukungan sosial.

\section{Analisa Pengaruh Focus Group Discussion} Tentang Pencegahan Risiko Bunuh Diri Terhadap Perilaku Risiko Bunuh Diri Pada Remaja Berisiko

Berdasarkan hasil perhitungan uji wilcoxon test, maka nilai $\mathrm{p}$ value $0.055(\mathrm{P}=0.000)>0.05$ sehingga disimpulkan maka Ho diterima yang berarti tidak ada pengaruh FGD (focus group discussion) tentang pencegahan risiko bunuh diri terhadap perilaku risiko bunuh diri pada remaja berisiko.

Hasil penelitian ini berbanding terbalik dengan penelitian lainnya, dengan hasil penelitian yang dilakukan Aprilia (2016) dengan judul penelitian"Efektivitas Focus Group Discussion untuk Mengurangi Stres Pada Siswa SMA yang Akan Menghadapi Ujian Nasional" menjelaskan bahwa pelaksanaan FGD terbukti efektif dalam mengurangi stres pada anak SMA yang akan menghadapi Ujian Nasional. Penelitian yang sama dilakukan oleh Budi (2017) tentang: pengaruh situasional terhadap kecemasan mahasiswa D III keperawatan dalam menghadapi ujian skill laboratorium menjelaskan bahwa mahasiswa D III Keperawatan yang akan menghadapai ujian skill laboratorium sering mengalami kecemasan. Dengan dilaksanakannya 
FGD pada mahasiswa DIII Keperawatan yang akan mengikuti ujian dapat menurunkan kecemasan mahasiswa DIII Keperawatan. Penelitian Ginting (2014) tentang efektifitas FGD terhadap peningkatan smoking self efficacy pada kelompok pria dewasa awal kategori sedang. Dalam penelitiaannya didapatkan hasil bahwa FGD efektif meningkatkan perilaku pada seluruh perokok untuk mengontrol keinginan merokok

Asumsi peneliti hal tersebut bisa terjadi karena pencegahan risiko bunuh diri pada remaja di pengaruhi oleh faktor internal dan ekstrernal. Faktor internal antara lain; dukungan keluarga dan mekanisme koping. Sedangkan faktor eksternal adalah dukungan teman sebaya dan faktor lingkungan. Dukungan teman sebaya dalam penelitian ini adalah pemberian dukungan berupa perhatian secara emosi, pemberian sikap menghargai. Selain itu intervensi yang diberikan pada responden hanya 1 kali melalui aplikasi zoom. Sehingga hal tersebut dapat mempengaruhi hasil penelitian. Berdasarkan penelitian yang lalu oleh Indarwati, Bayu, Syarieh (2013) mengatakan FGD diberikan 3 kali sehingga bisa mempengaruhi hasil.

\section{E. Keterbatasan Penelitian}

Berdasarkan penelitian yang telah dilakukan terdapat keterbatasan penelitian.

1. Teknik pengumpulan data penelitian ini menggunakan kusioner yang dibagikan dalam grup Whatsapp berupa google form tanpa melakukan tatap muka. Hal ini diwajibkan guna untuk menjalakan protokol kesehatan terkait physical distancing dikarenakan wabah COVID-19.

2. Focus Group Discussion diberikan melalui aplikasi ZOOM tanpa melakukan tatap muka. Hal ini diwajibkan guna untuk menjalakan protokol kesehatan terkait physical distancing dikarenakan wabah COVID-19.

\section{UCAPAN TERIMA KASIH}

\section{DAFTAR RUJUKAN}

Daftar rujukan hanya $\mathrm{m}$ Terima kasih penulis sampaikan kepada:

1. dr. Rudi Joegijantoro, MMRS, selaku Direktur Sekolah Tinggi Ilmu Kesehatan Widyagama Husada yang memberikan izin dalam pembuatan Tugas ini.

2. Abdul Qodir, S.Kep., Ners., M.Kep selaku ketua Program Studi Pendidikan Ners Sekolah Tinggi Ilmu Kesehatan Widyagama Husada yang memberikan izin dalam pembuatan Tugas ini.

3. Mizam Ari K. S.Kep., Ners., M.Kep selaku Penguji I yang telah memberikan saran dan masukkan tentang tugas ini.

4. Miftakhul Ulfa, S.Kep., Ners., M.Kep selaku Penguji II sekaligus pembimbing I yang telah memberikan saran dan masukkan tentang tugas ini.

5. Ahmad Guntur A, S.Kep., Ners., M.Kep selaku Penguji III sekaligus pembimbing II yang telah memberikan saran dan masukkan tentang tugas ini.

6. Drs. Frans Ketut Sunaryo, M.Si selaku Guru BK di SMAN yang telah mengizinkan dalam penelitian ini

\section{Daftar Rujukan}

Agustriyana, N. A. (2017). Fully Human Being Pada Remaja Sebagai Pencapaian Perkembangan Identitas. Jurnal Bimbingan Konseling Indonesia, 2(1), 9-11. $\quad$ Retrieved from 
https://www.researchgate.net/publication/320717 909_FULLY_HUMAN_BEING_PADA_REMA JA_SEBAGAI_PENCAPAIAN_PERKEMBAN GAN_IDENTITAS

Alfianto, A. G., \& Safitri, A. (2019). Efikasi Diri Siswa dengan Tanda Gejala Psikosis Awal dalam Mencari Bantuan Melalui Usaha Kesehatan Sekolah Jiwa. JI-KES (Jurnal Ilmu Kesehatan). https://doi.org/10.33006/jikes.v3i1.123

Aprilia, D.(2016). Ef Baggio, L., Palazzo, L. S., \& Aerts, D. R. G. de C. (2009). Suicide Planning Among Teenage Students: Prevalance and Associated Factors, 25(1), 142-150.

Badan Narkotika Nasional (BNN). (2012). Data Tindak Pidana Narkoba Provinsi Jawa Tengah Tahun 2007-2011. http://103.3.3.70.3/portal/index.php/konten/d etail/deputipemberantasan/data-

kasusnarkoba/10247/data-tindak-pidananarkobaprovinsi-jawa-tengah/tahun-2007-2 011. Diakses 8 Oktober 2019.

Burhannudin Ichsan. (2016). Pengantar Metodologi Penelitian Kedokteran Dan Kesehatan Masyarakat (S. dr. Triswi Widyanti Mugi Raharjanti, M.Kes, ed.). Surakarta: Muhammadiyah University Press.

Budi, Y. S., Wardaningsih, S., \& Afandi, M. (2017). Pengaruh situasional terhadap Kecemasan Mahasiswa DIII Keperawatan Dalam Menghadapi Ujian Skill Laboratorium. Tesis.

Cash, S. J., \& Bridge, J. A. (2010). Epidemiology of Youth Suicide and Suicidal Behavior, 21(5), 613619.
Dianovinina, K.(2018). Depresi Pada Remaja: Gejala dan Permasalahannya. Jurnal Psikologenesis, Volume 6, No 1.

Edi. (2014). DISKUSI KELOMPOK TERARAH Focus Group Discussion (FGD) (Prinsip-Prinsip dan Langkah Pelaksanaan Lapangan). Universitas Andalas: $\quad$ Padang

Gerritsen, A. (2011). Focus Group Discussions-a stepby-step guide.University of Limpopo \& VLIR project South Africa. Diakses dari https://www.slideshare.net/AnnetteGerritsen/fgd -manual pada tanggal 9 Maret 2020.

Ginting, M.D.F. (2014). Efektivitas Focus Group Discussion TerhadapPeningkatan Smoking Self Efficacy Pada Kelompok Pria Dewasa Awal Kategori Perokok Sedang. Program Pendidikan Magister Psikologi Profesi Fakultas Psikologi Universitas Sumatera Utara.

Gulo, W. (2010). Metodologi Penelitian. Jakarta : PT Grasindo.

Hurlock, Elizabeth B. (2011). Psikologi Perkembangan: Suatu Pendekatan Sepanjang Rentang Kehidupan. Jakarta: Erlangga.

Ibrahim, N., Sidik, S. M., Kar, P. C., Psy, M., Mukhtar, F., Awang, H., Ghaffar, A. (2017). Prevalence and Predictors of Depression and Suicidal Ideation Among Adolescents Attending Goverment Secondary Schools in Malaysia. Medical Journal Malaysia, 72(4), 221-227.

Kemenkes Ri. (2013). Riset Kesehatan Dasar; RISKESDAS. Jakarta: Balitbang

Kusumaryani, Merry. "Prioritaskan Kesehatan Reproduksi Remaja Untuk Menikmati Bonus Demografi” Lembaga Demografi UI 2017 (online) dalam 
http://ldfebui.org/wpcontent/uploads/2017/08/B

N-06- 2017.pdf diakses pada 20 Maret 2017.

Malangtimes.com.(2018, 10 Desember). Kenakalan

Remaja. Diperoleh 10 Desember 2019, dari https://www.malangtimes.com/tag/kenakalanremaja.

Marela, G, Wahab, A \& Marchira, C. (2017). Bullying Verbal Menyebabkan Depresi pada Remaja SMA di Kota Yogyakarta. Diambil dari https://journal.ugm.ac.id./bkm/article//downlod/8 183/20337. Diakses pada tanggal 8 Oktober 2019.

Mojtabai, Olfson, \& Han (2016). National Trends in the Prevalence and Treatment of Depression in Adolescents and Young Adults. American Academy of Pediatrics, November 2016. $\begin{array}{lll}\text { Diunduh } & 8 & \text { Oktober }\end{array}$ 2019darihttp://pediatrics.aappublications.org/con tent/pediatrics/early/2016/11/10/peds.20161878.full.pdf.

Mubasyiroh, R., Putri, I. Y. S., \& Tjandrarini, D. H. (2017). Determinan Gejala Mental Emosional Pelajar SMP-SMA di Indonesia Tahun 2015, 103-112.

Nanda, (2012). Diagnosa Keperawatan : Definisi dan Klasifikasi 2012-2014. Buku Kedokteran : EGC. Notoatmodjo, S. (2010). Metodologi Penelitian Kesehatan. Jakarta : Rineka Cipta.

Nock, M. K., Deming, C. A., Fullerton, C. S., Gilman, S. E., Goldenberg, M., Kessler, R, C., McCarroll, J. E., McLaughlin, K. A., Peterson, C., Schoenbaum, M., Stanley, B., \& Ursano, R. J. (2013). Suicide among soldiers: A review of psychosocial risk and protective factors. Psychiatry (New York). https://doi.org/10.1521/psyc.2013.762.97
Oppong Asante, K., Kugbey, N., Osafo, J., Quarshie, E. N. B., \& Sarfo, J. O. (2017). The prevalance and correlates of suicidal behaviours (ideation, plan an attempt) among adolescents in senior high schools in Ghana, SSM - Population Health, 3(February), 427-434. https://doi.org/10.1016/j.ssmph.2017.0.5.005.

Pratiwi, Anggun Ari. (2012). Hubungan Tingkat Pengetahuan Remaja Tentang Dampak Seks Bebas Dengan Perilaku Seksual Remaja di Desa Kweni Sewon Bantul Yogyakarta. Karya Tulis Ilmiah.

Potter \& Perry. (2009). Fundamental Keperawatan. Edisi 7. Jakarta : Salemba Medika

Sansone, R. A., \& Wiederman, M. W. (2015). Religiosity/spirituality: Relationships with nonsuicidal selfharm behaviors and attempted suicide. International Journal of Social Psychiatry.

https://doi.org/10.1177/0020764015579738

Sarwono. (2011). Psikologi Remaja.Edisi Revisi. Jakarta: Rajawali Pers.

Stuart,G.W. (2013). Psyciatric Nursing. (Edisi 10). Jakarta: $E G C$

Stuart.Gail.W (2016). Keperawatan Kesehatan Jiwa : Indonesia: Elsever.

Sugiyono. (2013). Metode Penelitian Pendidikan Pendekatan Kuantitatif, Kualitatif, dan R\&D. Bandung: Alfabeta.

Sutejo. (2017). Keperawatan Jiwa. Yogyakarta: PUSTAKA BARU PRESS.

Swarjana, I.K. (2016). Metodologi Penelitian Kesehatan (Edisi Revisi). Yogyakarta: ANDI. 
The Mental Health Recovery Institute. (2017). The 13

Suicide Warning Signs: A Guide for Managers.

Australai: The Mental Health Recovery Institute.

Retrieved from www.mhri.com.au

Undarwati, J \& Pratiwi, T. F. (2014). Suicide Ideation

Pada Remaja di Kota Semarang.Developmental

and Clinical Psychology, 3(1), 24-34.

http://doi.org/ISSN :2252-6358.

Vardanyan, A., Crape, B., Harutyunyan, T., \& Truzyan, N (2019). Risk factors and prevalence of adolescent depression in Yerevan,Armenia. Diunduh $\quad 8 \quad$ Oktober 2019 dari http://www.aua.am/chsr/UserFiles/File/n ew/Thesis\%202013/Armine\%20Vardanyan _2013.pdf

Wittouck, C., Van Autreve, S., Portzky, G., \& van Heeringen, K. (2014). A CBTbased psychoeducational intervention for suicide survivors: A cluster randomized controlled study. Crisis. https://doi.org/10.1027/0227$5910 / \mathrm{a} 000252$
Wenzel, A. (2017). The SAGE Encyclopedia of Abnormal and Clinical Psychology. Thousand Oaks, California: SAGE Publications.

World Health Organiza on (WHO). (2015), Adolescent Development: Topics at Glance WHO SEARO. (2017). Mental Health Status of Adolescents in South-East Asia: Evidence for Action. WHO Regional Office for South-East Asia.

Yosep, I. (2010). Keperawatan Jiwa. Bandung: Refika Aditama

ektivitas Focus Group Discussion untuk Mengurangi Stres Pada Siswa SMA yang Akan Menghadapi Ujian Nasional. Jurnal Studia Insania.

Andari, S. (2017). Fenomena Bunuh Diri di Kabupaten Gunung Kidul . Sosio Konsepsia , 7, 92.

Cite this article as: Nugraha, Kadek Dicky. dkk. (2020). Focus Group Discussion Tentang Pencegahan Risiko Bunuh Diri Terhadap Perilaku Risiko Bunuh Diri Pada Remaja Berisiko. Media Husada Journal of Nursing Science. Vol. 1(No.1),11-21. https://doi.org/10.33475/mhjns.vdiisi tim redaksi. 